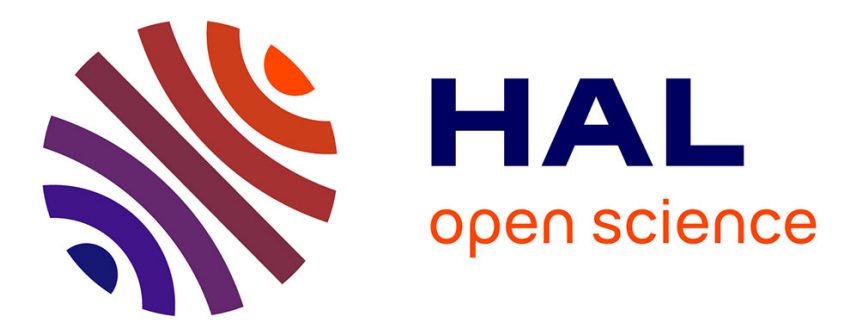

\title{
Stroke prevention in the young child with sickle cell anaemia
}

Lara Roberts, Sandra O’Driscoll, Moira C. Dick, Sue E. Height, Colin Deane, David E. Goss, Keith Pohl, David C. Rees

\section{- To cite this version:}

Lara Roberts, Sandra O'Driscoll, Moira C. Dick, Sue E. Height, Colin Deane, et al.. Stroke prevention in the young child with sickle cell anaemia. Annals of Hematology, 2009, 88 (10), pp.943-946. $10.1007 / \mathrm{s} 00277-009-0757-\mathrm{z}$. hal-00535062

\section{HAL Id: hal-00535062 \\ https://hal.science/hal-00535062}

Submitted on 11 Nov 2010

HAL is a multi-disciplinary open access archive for the deposit and dissemination of scientific research documents, whether they are published or not. The documents may come from teaching and research institutions in France or abroad, or from public or private research centers.
L'archive ouverte pluridisciplinaire HAL, est destinée au dépôt et à la diffusion de documents scientifiques de niveau recherche, publiés ou non, émanant des établissements d'enseignement et de recherche français ou étrangers, des laboratoires publics ou privés. 


\title{
Stroke prevention in the young child with sickle cell anaemia
}

\author{
Lara Roberts • Sandra O'Driscoll • Moira C. Dick • \\ Sue E. Height • Colin Deane • David E. Goss • \\ Keith Pohl • David C. Rees
}

Received: 6 May 2009 / Accepted: 8 May 2009 / Published online: 20 May 2009

(C) Springer-Verlag 2009

\begin{abstract}
Cerebrovascular disease resulting in stroke is a serious and preventable complication of sickle cell anaemia (SCA). Children at high risk of preventable stroke can be identified by transcranial Doppler ultrasound (TCD). Current guidelines in the UK recommend annual TCD screening from 3 years, although studies suggest an earlier peak incidence, between 2 and 5 years. A single centre retrospective review was undertaken to identify the prevalence of stroke and success of TCD screening in young children. We report five episodes of stroke in under $3 \mathrm{~s}$ and outcome of TCD screening in children under 3, compared to over 3. TCD analysis was as successful in the 2-3-year age group as in the 3-4-year group. We therefore propose that all children with SCA should be offered TCD screening from the age of 2 years. Furthermore, infants with high risk features of SCA should undergo a first attempt at TCD screening even earlier.
\end{abstract}

Keywords Sickle cell anaemia · Transcranial Doppler . Stroke $\cdot$ Cerebrovascular accident $\cdot$ Children

\footnotetext{
L. Roberts $\cdot$ S. O'Driscoll $\cdot$ M. C. Dick · S. E. Height $\cdot$

D. C. Rees $(\square)$

Department of Paediatric Haematology, Kings College Hospital, Denmark Hill,

London SE5 9RS, UK

e-mail: david.rees@kcl.ac.uk

C. Deane $\cdot$ D. E. Goss

Vascular Laboratory, Kings College Hospital,

London, UK

K. Pohl

Department of Paediatric Neurology, Evelina Children's Hospital, London, UK
}

\section{Introduction}

Sickle cell anaemia (SCA) is an inherited condition characterised by haemolysis and vaso-occlusive episodes causing acute pain and organ damage. Cerebrovascular occlusive disease, predominantly affecting the middle cerebral arteries, resulting in stroke is a serious and preventable complication of SCA, most common in homozygotes (HbSS). SCA has been shown to be the most significant risk factor for stroke in the USA childhood population [1]. Eleven percent of strokes occur by the age of 20 years in patients with SCA, with the highest rate of 1 per 100 patient years in those aged 2 to 5 years [2]. Progressive cerebrovascular disease and stroke are largely preventable complications of SCA. The Stroke Prevention Trial in Sickle Cell Anemia (STOP) study demonstrated that early detection of abnormal cerebral blood vessel flow by transcranial Doppler ultrasonography (TCD) and initiation of a blood transfusion programme in those with elevated measurements was successful in reducing the rate of first stroke [3]. This has resulted in the current guidelines in the UK recommending screening of children with SCA by TCD from the age of 3 years [4, 5]. Children with abnormal TCD velocities (greater than $200 \mathrm{~cm} / \mathrm{s}$ in internal carotid (ICA) or middle cerebral artery (MCA) on two occasions) should commence a blood transfusion programme, to prevent a first stroke [3].

Other factors may be important in predicting an increased risk of stroke. Miller and colleagues found dactylitis, severe anaemia and leucocytosis in the first 2 years of life predictive of future adverse outcome [6]. Elevated TCD measurements have been correlated with lactate dehydrogenase (LDH) [7], in addition to low haemoglobin and aspartate transaminase (AST) [8]. Markers of haemolysis, such as LDH and AST, may therefore be useful in stroke prediction. Underlying 
genetic risk is also recognised with an established association between the tumor necrosis factor (TNF; -308)G/A variant and risk of large vessel stroke. Other genetic variants, such as IL4R $503 \mathrm{~S} / \mathrm{P}$ and LTC4S (-444) A/C may also predispose to increased risk of large vessel stroke in SCA [9, 10].

We describe five cases of stroke in children with SCA occurring at less than 3 years of age over a 16-year period. We report our experience of TCD in children aged 2 to 4 years of age and propose current guidance be revised to initiate routine screening from 2 years, with selected screening in younger children with high risk features.

\section{Materials and methods}

Case histories

A single centre retrospective review of cases with stroke occurring in children less than 3 years was undertaken. The case notes were reviewed to establish age at presentation, precipitating events, features of high risk disease, stroke distribution, previous TCD results and clinical outcome. The review was conducted as part of an audit into the effectiveness of the TCD programme and, in particular, the success rate of screening in young children.

Transcranial Doppler screening in early childhood

We retrospectively reviewed outcomes in children undergoing TCD screening in age groups 2 to 3 years in comparison with those 3 to 4 years. TCD imaging was performed in a vascular laboratory by trained vascular scientists. Intracerebral blood velocity was measured according to the protocol used in the STOP study [3] using TCD imaging. Previous evaluation of TCD imaging versus TCD scanning had shown that both methods gave the same results when used according to strict established protocols [8]. TCD measurements were first attempted between the ages of 2 and 4 years depending on when the child was seen in clinic. TCD imaging was considered normal when the maximum velocities were less than $170 \mathrm{~cm} / \mathrm{s}$ in the MCA, distal ICA and at the ICA bifurcation bilaterally. A velocity, in any one of these vessels, of more than $200 \mathrm{~cm} / \mathrm{s}$ was reported as abnormal. Velocities between 170 and $200 \mathrm{~cm} / \mathrm{s}$ in any of the MCA or distal ICA and velocities greater than $170 \mathrm{~cm} / \mathrm{s}$ in anterior cerebral artery (ACA) or posterior cerebral artery were considered conditional results.

Data examined included type of sickle cell disease, age, success and result of TCD. Children in these age groups were identified from our database of SCA children from May 2005.

\section{Results}

Case histories

Five cases of stroke in less than 3 years old were identified. All cases were HbSS, characteristics of which are summarised in Table 1.

Case 1 presented in 1992 at the age of 18 months, with a right hemiparesis. Computed tomography (CT) of his brain, without contrast at this time, was normal. He was commenced on a blood transfusion programme, which was discontinued soon after due to poor compliance. He represented at age 3 years 3 months with a left hemiparesis associated with an aplastic crisis triggered by parvovirus. Again, CT brain failed to demonstrate a causative lesion but a transfusion program was successfully re-initiated. Magnetic resonance imaging (MRI) of his head 4 years after the second event revealed signal alteration consistent with previous ischaemia in the right MCA and right ACA artery territories with an attenuated right ACA evident on angiographic sequences. He has continued on a regular blood transfusion programme for the last 16 years without neurological deterioration or evidence of progression of cerebrovascular disease.

Table 1 Characteristics of children under 3 years presenting with stroke

\begin{tabular}{llllll}
\hline & Case 1 & Case 2 & Case 3 & Case 4 & Case 5 \\
\hline Year of stroke & 1992 & 1992 & 1994 & 1996 & 2007 \\
Age (years) & 1.6 & 1.9 & 1.8 & 1.4 & 2.9 \\
Precipitant & No & No & Yes & Yes & No \\
High risk criteria & Yes & Yes & Yes & Unknown & Yes \\
Focal signs & Yes & Yes & Yes & Yes & Yes \\
Imaging & CT & CT & CT & CT & CT/MRI \\
Distribution & Normal & R MCA & Diffuse & L MCA, ACA \\
Outcome & Ongoing impairment & Ongoing impairment & Ongoing impairment & Progressive impairment & Full recovery \\
\hline
\end{tabular}

${ }^{\text {a } H i g h ~ r i s k ~ c r i t e r i a ~ a s ~ d e f i n e d ~ b y ~ M i l l e r ~ e t ~ a l . ~[6]: ~ a n y ~ o f ~ d a c t y l i t i s, ~ h a e m o g l o b i n ~ l e s s ~ t h a n ~} 7 \mathrm{~g} / \mathrm{dL}$ or leucocytosis (in the absence of infection) at less than 2 years 
Case 2 was the twin sibling of case 1 and presented age 23 months, with an acute left hemiparesis accompanied by a focal seizure. CT brain confirmed ischaemic pathology in the right MCA territory, with stenosis of the right MCA and distal ICA on angiographic sequences. Regular blood transfusions have continued for the last 16 years. No further neurological events have occurred and there has been no progression of cerebrovascular disease on repeat imaging.

Case 3 presented age 19 months, with a febrile illness associated with vomiting. A diagnosis of meningitis was confirmed following lumbar puncture. During the course of the illness, he developed a right-sided hemiplegia, facial palsy and ptosis. CT head revealed evidence of infarction in posteroinfero-occipital lobes and the left frontal lobe, with associated cerebral oedema. This was consistent with the acute vasculitic process. TCD measurements were normal. A programme of regular blood transfusions was commenced. The patient was poorly compliant, further TCD remained normal with no further neurological events and he withdrew from the transfusion programme after 10 months.

Case 4 presented age 17 months following a 5-day febrile illness. He was found to be drowsy with an acute right-sided stroke. MRI head revealed multiple high signal ischaemic lesions in the right MCA territory corresponding to evident right MCA narrowing on angiographic sequences. Despite compliance with regular transfusions, maintaining his $\mathrm{HbS}$ below $30 \%$, he has had progressive narrowing of his intracerebral blood vessels. He is now receiving hydroxycarbamide in addition to transfusions and is under consideration for a cerebral revascularisation procedure.

Case 5 presented, at 2 years 11 months, just prior to his first scheduled TCD. He had unprecipitated decreased left hand function. CT and MRI demonstrated a right parietal infarct in the right MCA territory. TCD imaging during this admission revealed bilateral abnormal velocities $(214 \mathrm{~cm} / \mathrm{s}$ right MCA, $250 \mathrm{~cm} / \mathrm{s}$ left MCA). Following the initiation of a blood transfusion regime, he has regained full function of his hand.

Cases 1, 2 and 5 had leucocytosis and baseline haemoglobin of less than $7 \mathrm{~g} / \mathrm{dL}$. There was a history of prior dactylitis in case 3 only. Acute data were not available for case 4 . Cases $2-5$ all commenced a regular transfusion programme. All five cases were male.

Transcranial Doppler screening in early childhood

We identified 115 children from our database born between June 2001 to December 2005 who were eligible for first TCD between the ages of 2 and 4 years. TCD scans were reviewed over a 2.5-year period (May 2005 to December 2007). Twenty-one of these patients were no longer attending clinic or were referred after the age of four. Four patients had multiple scans and one parent refused TCD. Nine patients under regular review were over 4 years at the time of first TCD, and 24 children had not yet had their first TCD. Thus, 64 TCDs were undertaken within the 2- to 4-year age group and are the basis of our review.

The majority of these children had $\mathrm{HbSS}(73 \%)$, with HbSC accounting for $21.1 \%$ and the remaining $8.9 \%$ being other compound heterozygotes. The median age at the time of TCD was 3.05 years. Further results are summarised in Table 2 below. There were no significant differences between failure rates $(4 \%$ versus $10 \%)$ in younger compared to older children. There are significantly more children aged 2 to 3 years still awaiting first TCD (15 versus 9$)$. There was one conditional scan in an infant aged 2-3 years compared with four conditional and two abnormal scans in older children. This was not statistically significant. All abnormal scans occurred in children with HbSS.

\section{Discussion}

It is well known that unexpected stroke due to cerebrovascular disease with vessel narrowing occurs at a significant frequency in infants with SCA at less than 3 years of age. The Cooperative Study of Sickle Cell Disease demonstrated that the highest risk of stroke was in children aged 2-5 years [2]. It has also been shown that those at risk can be predicted by TCD [11]. Children with high flow velocity in intracranial vessels on TCD (greater than or equal to $170 \mathrm{~cm} / \mathrm{s}$ ) have a stroke rate of $10 \%$ to $15 \%$ per annum compared with an overall risk in children with SCA of less than $1 \%$ per year [11]. Furthermore, this group later demonstrated that prophylactic blood transfusion, maintaining $\mathrm{HbS}$ below $30 \%$ in those with abnormal TCD velocities $(>200 \mathrm{~cm} / \mathrm{s})$, is effective in preventing stroke [3]. We identified five episodes of stroke in under 3 s over a 16-year period in a single institution. Four of these cases may have been identifiable and preventable. Case 3, however, was considered a secondary complication following meningitis, as TCD measurements were normal at

Table 2 Outcomes of TCD screening in 2-3 years compared to 3-4 years

\begin{tabular}{lll}
\hline Age & $\begin{array}{l}\text { 2-3years } \\
\text { Number of patients (\%) }\end{array}$ & $\begin{array}{l}\text { 3-4years } \\
\text { Number of patients (\%) }\end{array}$ \\
\hline Completed & 24 & 40 \\
Successful & $23(96)$ & $36(90)$ \\
Normal & $20(83.3)$ & $27(67.5)$ \\
Failed & $1(4.2)$ & $4(10)$ \\
Inadequate & $2(8.3)$ & $3(7.5)$ \\
Conditional & $1(4.2)$ & $4(10)$ \\
Abnormal & 0 & $2(5)$ \\
\hline
\end{tabular}


both acute presentation and follow-up. TCD screening was not routinely undertaken during the time period over which cases 1 to 4 presented (1992-1996). Three of four children with potentially preventable stroke (cases 1,2 and 5) had features to suggest a higher risk of adverse outcome with leucocytosis and severe anaemia at less than 2 years of age. It may be appropriate to use markers of haemolysis, such as low haemoglobin, raised AST [8] and LDH [7] or features described by Miller and colleagues [6], to guide earlier intervention and screening for adverse outcome. Studies investigating the use of these markers in initiating TCD screening before 2 years of age to predict future risk of stroke would be valuable.

Two of the strokes described above occurred in twin siblings, a few months apart. It has been previously reported that abnormal TCD measurements and stroke are more common in children with SCA, who have a sibling with SCA and either abnormal TCD velocities or prior stroke [12, 13]. Earlier TCD screening should be considered for siblings with SCA if there is a family history of sickle-related cerebrovasculopathy. Recent studies have demonstrated genetic variants associated with increased risk of stroke, most convincingly TNF (-308) G/A [9, 10]. It may be possible to utilise genotyping for this and other potential variants in the future to identify infants at higher risk of stroke and selectively instigate earlier TCD screening.

Following the STOP study [3], guidance was issued in the USA recommending TCD screening from 2 years of age [14]. In the UK, however, annual TCD screening is recommended in children with SCA from 3 years of age [4, 5]. This may stem from a perception that younger children may be less cooperative and TCD technically difficult. In our experience, TCD can be performed successfully in those less than 3 years. There was no significant difference in success or failure rates of TCD in those aged 2 to 3 years compared with older children, with failure rates being low in both groups.

Given the incidence of stroke in children with SCA peaks between 2 and 5 years and TCD is as successful, 2 years may be a more appropriate age point to recommend for a national screening programme and is the policy we have now adopted in our unit. However, in our series, three children had an unprecipitated stroke under the age of 2 years and would have been missed by any proposed or existing screening programme. Vigilance for features which suggest a high risk of stroke in infants under 2 years should be encouraged. The presence of a family history of SCA-related stroke, prior neurological events, low haemoglobin or high LDH should alert the physician to a possible higher risk of stroke and TCD should be attempted before age 2 years. Sedation may be appropriate to facilitate TCD in such high risk infants, although this may elevate TCD measurements and cause false positive results.

\section{References}

1. Earley CJ, Kittner SJ, Feeser BR, Gardner MS, Epstein A, Wozniak MA, Wityk R, Stern BJ, Price TR, Macko RF, Johnson C, Sloan MA, Buchholz D (1998) Stroke in children and sickle cell disease. Neurology 51:169-176

2. Ohene-Frempong K, Weiner SJ, Sleeper LA, Miller ST, Embury S, Moohr JW, Wethers DL, Pegelow CH, Gill FM, Cooperative study of Sickle Cell Disease (1998) Cerebrovascular accidents in sickle cell disease: rates and risk factors. Blood 91:288-294

3. Adams RJ, McKie VC, Hsu L, Files B, Vichinsky E, Pegelow C, Abboud M, Gallagher D, Kutlar A, Nichols FT, Bonds DR, Brambilla D (1998) Prevention of first stroke by transfusions in children with sickle cell anaemia and abnormal results of transcranial Doppler ultrasonography. N Engl J Med 339:5-11. doi:10.1056/NEJM199807023390102

4. Paediatric Stroke Working Group Stroke in childhood (2004) Clinical guidelines for diagnosis, management and rehabilitation. Royal College of Physicians, London

5. NHS Sickle and Thalassaemia Screening Program. Sickle Cell Disease in Childhood: Standards and guidelines for clinical care. Available at http://www.sickleandthal.org.uk/Documents/ ProgrammeSTAN.pdf. Accessed 9th December 2007.

6. Miller ST, Sleeper LA, Pegelow CH, Enos LE, Wang WC, Weiner SJ, Wethers DL, Smith J, Kinney TR (2000) Prediction of adverse outcomes in children with sickle cell disease. N Engl J Med 342:8389. doi:10.1056/NEJM200001133420203

7. O'Driscoll S, Height SE, Dick MC, Rees DC (2008) Serum lactate dehydrogenase activity as a biomarker in children with sickle cell disease. Br J Haematol 140(2):206-209

8. Rees DC, Dick MC, Height SE, O'Driscoll S, Pohl KRE, Goss DE, Deane CR (2008) A simple index using age, hemoglobin and aspartate transaminase predicts increased intracerebral blood velocity as measured by transcranial Doppler scanning in children with sickle cell anaemia. Paediatrics 121:e1628-e1632. doi:10.1542/peds.20072771

9. Hoppe C, Klitz W, Cheng S, Apple R, Steiner L, Robles L, Girard T, Vichinsky E, Styles L, Investigators CSSCD (2004) Gene interactions and stroke risk in children with sickle cell anaemia. Blood 103:23912396. doi:10.1182/blood-2003-09-3015

10. Hoppe C, Klitx W, D'Harlingue K, Cheng S, Grow M, Steiner L, Noble J, Adams R, Styles L, Stroke Prevention Trial in Sickle Cell Anemia (STOP) Investigators (2007) Confirmation of an association between the $\mathrm{TNF}(-308)$ promoter polymorphism and stroke risk in children with sickle cell anaemia. Stroke 38:2241-2246. doi:10.1161/ STROKEAHA.107.483115

11. Adams R, McKie V, Nichols F, Carl E, Zhang DL, McKie K, Figueroa R, Litaker M, Thompson W, Hess D (1992) The use of transcranial ultrasonography to predict stroke in sickle cell disease. N Engl J Med 326:605-610

12. Kwiatkowski JL, Hunter JV, Smith-Whitley K, Katz ML, Shults J, Ohene-Frempong K (2003) Transcranial Doppler ultrasonography in siblings with sickle cell disease. Br J Haematol 121:932-937. doi:10.1046/j.1365-2141.2003.04276.x

13. Driscoll MC, Hurlet A, Styles L, McKie V, Files B, Olivieri N, Pegelow C, Berman B, Drachtman R, Patel K, Brambilla D (2003) Stroke risk in siblings with sickle cell anaemia. Blood 101:24012404. doi:10.1182/blood.V101.6.2401

14. National Heart, Lung and Blood Institute (1997) Clinical alert. Department of Health and Human Services, National Heart, Lung and Blood Institute, Bethesda, MD 